\title{
Cytomegalovirus Incidence in Pregnant Women with Recurrent Abortion
}

\section{Sana A. Abdul Wahab*}

Basic Science Department, College of Dentistry, University of Baghdad, Bab Al Mozam, Iraq

\begin{abstract}
Cytomegalovirus belongs to the family herpesviridae, it is important cause of abortion, mental retardation and fetal death. This study was conducted to determine the occurrence of IgM and IgG antibodies in sera and CMV antigens in saliva in women with recurrent abortion and the effect of the virus on some haematological criteria in those women. It is concluded that IgG titre is higher in women who were between 36-40 years of age than other ages. After 40 years fetal death increased especially in women with positive IgG. Furthermore, the virus affect haematological criteria causing anemia and leucopenia.
\end{abstract}

Keywords: Cytomegalovirus; Antigens; Leucopenia

\section{Introduction}

Cytomegalovirus belongs to the family herpesviridae of betaherpesvirnae subfamily. It is also known as HHV-5. Primary infection caused by them is usually subclinical, but when it is associated with humans it causes several diseases.

Human cytomegalovirus is important as it causes abortion and in more cases congenital damage fetal death and mental retardation. Congenital CMV is the most common intrauterine infection [1-7].

Fetal infection and the risk of associated damage is higher after primary infection. The risk for fetal infection is greatest with maternal primary CMV infection and much less likely with recurrent infection as the virus remains latent in the host cell after initial infection [8-10]. Infectious HCMV may be shed in body fluids of any infected person and can be found in saliva, tears, semen and breast milk [6].

The present study aims to determine the presence of HCMV antibody in serum samples and the virus in saliva in women with more than one abortion at different age groups and the effect of the virus on some hematological criteria in these women $[11,12]$.

\section{Materials and Method}

Fifty pregnant women were included in this study at age range between (20-45) years.

Serum and saliva samples were collected from pregnant women at different ages, the samples were tested for anti CMV IgG and IgM in serum and the presence of the virus in saliva as saliva use in clinical diagnosis or screening purpose [13-15].

The percent of hemoglobin and white blood cell counts were also estimated in these women.

The control group was twenty women without any abortion. Five $\mathrm{ml}$ of whole unstimulated saliva was collected using plastic disposable polythelene bottles, saliva was centrifuged at $3000 \mathrm{rpm}$ for 10 minutes within one hour after collection to remove debris, the supernatant were aspirated and put in ependroff tube for assay. Immunofluorescence was used for detection of CMV Ag by using immunofluorescent slides that contain the CMV virus grown on fibroblast cells (medic co). 10 $\mu \mathrm{l}$ saliva was added to each well and acetone was added to for fix for $10 \mathrm{~min}$ at $4^{\circ} \mathrm{C}$, thenit was rinsed thrice with phosphate buffer saline and was left to dry at room temperature; then the slides were blocked with blocking buffer at room temperature for $2 \mathrm{hrs}$ and then washed with phosphate buffer saline and was again dried at room temperature.
Fluorescent tagged antibody diluted at a level of 1:10 with blocking buffer was applied to cover the sample preparation and was incubated over night at $4^{\circ} \mathrm{C}$, then slides were washed 3 times and was examined by immunofluorescence microscope for detection of HCMV antigen with cytoplasmic apple green fluorescence. Enzyme linked immunoassay (ELISA) was used for the detection of CMV antibodies IgM and IgG in the leaflet of the kit (Biocheck). Chi-square was used for statistical analysis to compare the results $[16,17]$.

\section{Results}

The percent of immoglobulin at age twenty was $16.7 \%$ while at age forty to forty five was 21.7 (Table 1), the patient women at age more than thirty years show more percent of abortion (Figure 1 and Table 3). The titres of anticytomegalovirus immunoglobulin $\mathrm{G}$ were higher at age thirty six to age forty five, so there is elevated serum titres of CMVspecific IgG antibody (Table 2 and Figure 2).

Figure 3 shows the statistical P-value comparison between age group according to fetal death, and shown statistically significant differences in P-value, on different ages at age more than thirty (Table 2). The virus

\begin{tabular}{|c|c|c|c|c|c|}
\hline Age group & No. & No. with abortion & Percent $\%$ & Chi-square & P-value \\
\hline $20-25$ & 10 & 2 & 20 & 0.325 & $\begin{array}{c}0.698 \\
\text { NS }\end{array}$ \\
\hline $26-30$ & 10 & 2 & 20 & 0.325 & $\begin{array}{c}0.698 \\
\text { NS }\end{array}$ \\
\hline $31-36$ & 10 & 3 & 30 & 1.032 & $\begin{array}{c}0.154 \\
\text { NS }\end{array}$ \\
\hline $36-40$ & 10 & 5 & 50 & 2.147 & 0.048 S \\
\hline $41-45$ & 10 & 6 & 60 & 2.478 & 0.0 .043 S \\
\hline Total & 50 & 18 & & 4.153 & 0.0415 \\
\hline
\end{tabular}

Chi-square $=4.153 P=0.0415 P<0.05$ Significant

Table 1: The percent of abortion at different age group.

*Corresponding author: Sana A. Abdul Wahab, Basic Science Department College of Dentistry, University of Baghdad, Bab Al Mozam, Iraq, E-mail: sana195083@yahoo.com

Received December 07, 2012; Accepted December 26, 2012; Published December 31, 2012

Citation: Abdul Wahab SA (2012) Cytomegalovirus Incidence in Pregnant Women with Recurrent Abortion. J Bioanal Biomed 4: 101-103. doi:10.4172/1948593X.1000071

Copyright: @ 2012 Abdul Wahab SA. This is an open-access article distributed under the terms of the Creative Commons Attribution License, which permits unrestricted use, distribution, and reproduction in any medium, provided the original author and source are credited. 
Citation: Abdul Wahab SA (2012) Cytomegalovirus Incidence in Pregnant Women with Recurrent Abortion. J Bioanal Biomed 4: 101-103. doi:10.4172/1948-593X.1000071

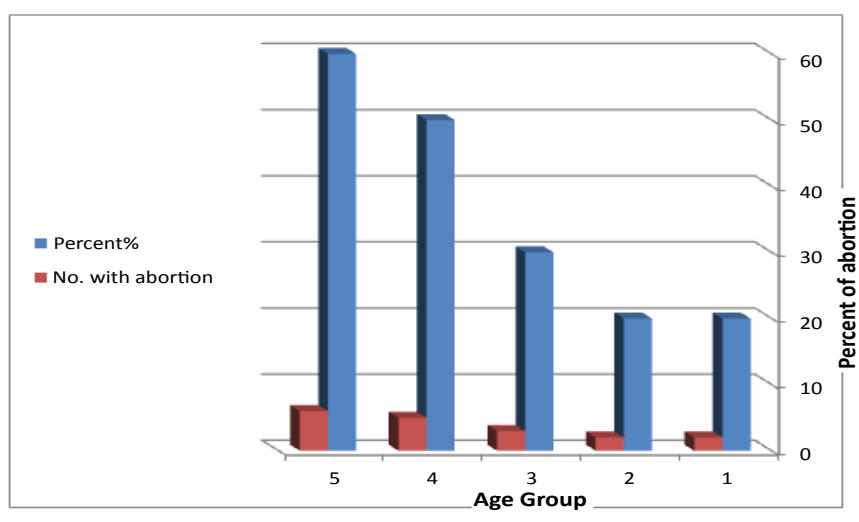

Figure 1: Percent of abortion at different age group.

\begin{tabular}{|c|c|c|c|c|c|}
\hline Age group & No. & TitrelgG & TitrelgM & Chi-square & \begin{tabular}{c} 
P-value \\
\hline $20-25$
\end{tabular} \\
\hline 20 & 2 & 1.7 & 0.365 & $\begin{array}{c}0.268 \\
\text { NS }\end{array}$ \\
\hline $31-36$ & 10 & 1.4 & 1.9 & 0.285 & $0.432 \mathrm{NS}$ \\
\hline $36-40$ & 10 & 1.8 & 1.3 & 1.008 & $\begin{array}{c}0.247 \\
\text { NS }\end{array}$ \\
\hline $41-45$ & 10 & 2.1 & 1.2 & 2.24 & $0.047 \mathrm{~S}$ \\
\hline Total & 50 & 2.3 & 1.1 & 2.669 & $0.041 \mathrm{~S}$ \\
\hline
\end{tabular}

Chi-square $=0.072 P=0.788 P>0.05$ Non Significant

Table 2: TitrelgG and lgM.

\begin{tabular}{|c|c|c|c|c|c|c|}
\hline Age group & No. & No.+VelgG & No.+VelgM & Death & Chi-square & P-value \\
\hline $20-25$ & 10 & 1 & 4 & 1 & 2.001 & $\begin{array}{c}0.056 \\
\text { NS }\end{array}$ \\
\hline $26-30$ & 10 & 2 & 5 & 2 & 2.136 & 0.048 S \\
\hline $31-35$ & 10 & 5 & 2 & 2 & 2.135 & 0.048 S \\
\hline $36-40$ & 10 & 6 & 2 & 3 & 2.365 & $0.043 \mathrm{~S}$ \\
\hline $41-45$ & 10 & 7 & 3 & 4 & 3.024 & $0.041 \mathrm{~S}$ \\
\hline Total & 50 & 21 & 10 & 12 & 2.301 & 0.0316 \\
\hline
\end{tabular}

Chi-square $=2.301 P=0.0316 P<0.05$ Significant

Table 3: IgG and IgM avidity in pregnant women.

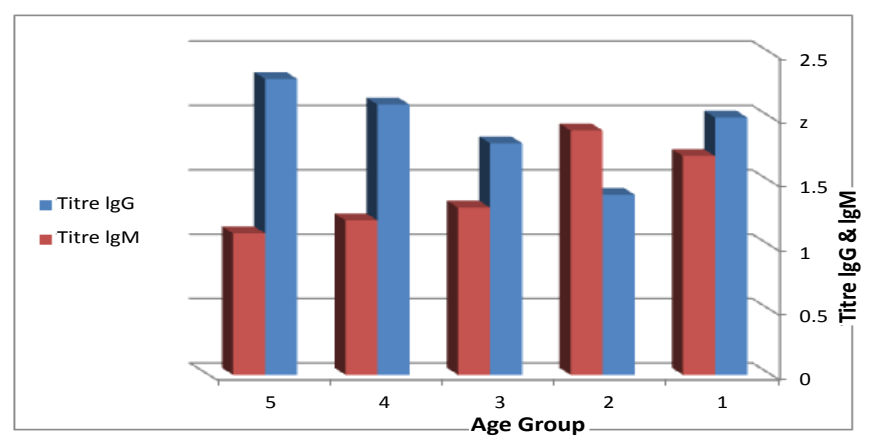

Figure 2: Elevated serum titres of CMV-specific IgG antibody.

at age 25 years present in saliva only in one while increasing after thirty. P-value was (0.048-0.041) (Table 5).

The number of abortions at age more than forty five is higher than that of twenty or thirty and also the percent of IgG percent is higher when compared with IgM (Figure 1).

Fetal death showed only in one women at the age more than twenty that had positive IgG while it increases more at the age of 30 (Table 3).

The virus is present in saliva of pregnant women at age twenty while at age more than thirty the presence of the virus in saliva was ranged between $3-4 \%$ (Figure 3).

\section{Discussion}

The number of abortions is highly significant at age group thirty six to forty five years compared with twenty to thirty. The titre of IgG is higher at age more than thirty and this indicates that cytomegalovirus infection is usually latent with potential for reactivation and this in agreement with reference [13]. Measurement of immunoglobulin G is important as Anticylomegalovirus IgG is produced in primary infection and the rising titers of it can be used as markers of acute infection and this is particularly useful in diagnosing recurrent infections.

Figure 3 and Table 4 indicates that the women at the age more than

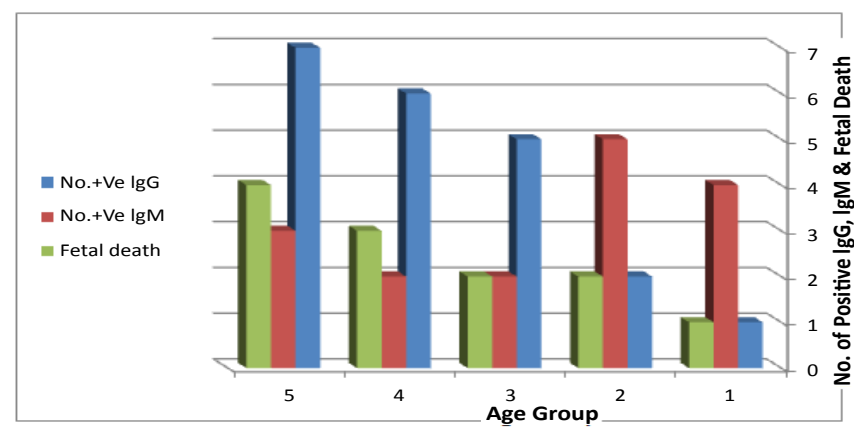

Figure 3: Statistical P-value comparison between age group according to fetal death.

\begin{tabular}{|c|c|c|c|c|c|}
\hline Age group & No. & No. with anemia & $\begin{array}{c}\text { WBC count } \\
\text { less than } \\
\text { 2500cells }\end{array}$ & Chi-square & P-value \\
\hline $20-25$ & 10 & 4 & 1 & 1.023 & $\begin{array}{c}0.256 \\
\text { NS }\end{array}$ \\
\hline $26-30$ & 10 & 5 & 1 & 1.126 & $\begin{array}{c}0.241 \\
\text { NS }\end{array}$ \\
\hline $31-36$ & 10 & 5 & 3 & 2.11 & 0.048 S \\
\hline $36-40$ & 10 & 6 & 4 & 2.365 & 0.042 S \\
\hline $41-45$ & 10 & 4 & 6 & 2.365 & 0.042 S \\
\hline Total & 50 & 24 & 15 & 2.189 & 0.0129 \\
\hline
\end{tabular}

${ }^{*}$ Chi-square $=2.189 P=0.0129 P<0.05$ Significant ${ }^{* *} P>0.05$ Non significant

Table 4: Relationship between the CMV and (women with anemia and leucopenia)

\begin{tabular}{|c|c|c|c|c|}
\hline Age group & No. & $\%$ positive & \% negative & p-value \\
\hline $20-25$ & 10 & 1 & 9 & \\
\hline $26-30$ & 10 & 1 & 9 & \multirow{2}{*}{$0.048 \mathrm{~S}$} \\
\hline $31-35$ & 10 & 3 & 7 & \\
\hline $36-40$ & 10 & 4 & 6 & \\
\hline $41-45$ & 10 & 4 & 6 & \\
\hline Total & 50 & & & \\
\hline
\end{tabular}

${ }^{*}$ Chi-square $=2.09 P=0.0129 P<0.05$ Significant ${ }^{* *} P>0.05$ Non significant Table 5: Detection of cytomegalovirus in saliva. 
Citation: Abdul Wahab SA (2012) Cytomegalovirus Incidence in Pregnant Women with Recurrent Abortion. J Bioanal Biomed 4: 101-103. doi:10.4172/1948-593X.1000071

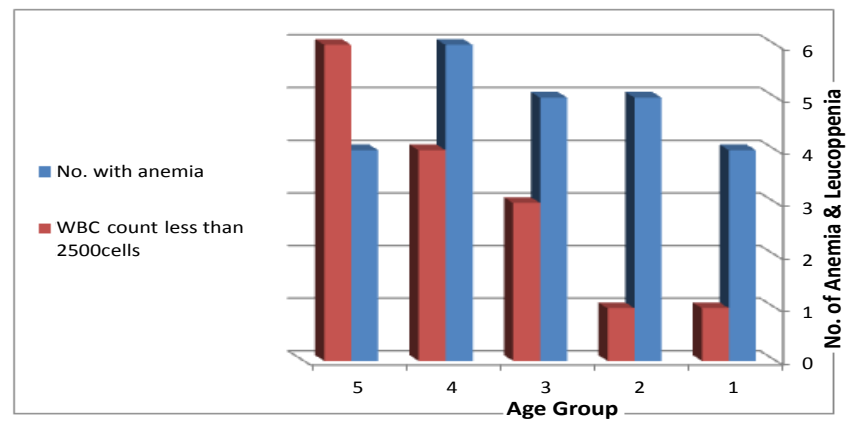

Figure 4: Relationship between the WBC and (women with anemia and leucopenia).

thirty six show anemia and leukoperia and this increases as, the age reaches more than forty and show significantly at p-value (Table 4).

Because the disease in the mother is asymptomatic it is believed to produce infections that may persist in a latent state and periodically flare up, resulting in the excretion of infections virus. Fetal infections and abortion can result from such a flare up of CMV during pregnancy; the titre of CMV-IgG is higher at age more than thirty five and this indicates that the virus reactivated during the recurrent infections and/ causes fetal death and may modify cell damage in the fetus [14-17].

Pregnant women excretes the virus in their saliva which indicates that the virus is associated with salivary glands [5].

Cytomegalovirus causes leukopenia and anemia as the virus has great effect on immune cells and leukocytes that causes immunosupression especially in pregnant women (Figure 4) [18].

\section{References}

1. Ablfors K, Ivarrson S, Harris (2001) Secondary Maternal Cytomegalovirus Infection-A Significant Cause of Congenital Disease. Pediatrics 107: 12271228.

2. Barry S, Edwards M (1999) Quantitative Analysis of Latent Human Cytomegalovirus. J Virol 4806-4812.
3. Doerr HW, Braun R, Munk K (1985) Human cytomegalovirus infection: recent developments in diagnosis and epidemiology. klin-wochenschr 63: 241-251.

4. Demmler GJ (1991) Summary of work shop on surveillance of congenital cytomegalovirus disease. Rev-infect Dis 13:315-329.

5. Fowler KB, Stagno S, Pass RF (2004) interval between births and risk of congenital CMV infection. Clin Infect Dis 1035-1037.

6. Geo JF, Brooks J, Butel S (1995) Nicholas ornston (medical microbiology) 370378.

7. Mijanbvic D (1992) [Primary and recurrent cytomegalovirus infection in pregnancy]. 120: 324-327.

8. Massimo DP, Carlo A, Maria TM, Alessia P, Pierangelo C (2009) Incidence and Risk of CytomegalovirusInfection during Pregnancy in an Urban Area of Northern Italy. J Infections disease of Obstetric and Gynecology.

9. Nibolini U, Tassis B, Fogliani R, Galimberi A, Pereivalle E, et al. prental diagnosis of congenital cytomegalovirus infection. Prenatdiagno 19903-199061.

10. Robert FP, Changpin Z, Ashley E, Tina S, William A, et al. (2009) Vaccine Prevention of Maternal Cytomegalovirus Infection. N Engl J Med 360: 1191 1199.

11. Slots JO, Martin AT (1992) Contemporary Oral Microbiology and Immunology.

12. Stango SM, Remington JS (1995) Infectious Diseases of the Fetus and Newborn Infant 3l: 2-353.

13. Strackhouse FA Kumar A, Mair GA, Dyke JW (1991) Cytomegalovirus infection and excretion in residents of nursing home. J Med Virol 34: 209-211.

14. Sukhikh GT, Dadal, Lan LG, Van'Ko LV kalafat TI, Sidellinkova VM, et al (1992) 3: 30-33.

15. Wills T (2006) Department of medicine division of infectious diseases, University of South Florida, College of Medicine, J Med.

16. Wesley AV, David CB, Robert JK, Thomas JP (essentials of medical microbiology (4thedn).

17. Whitley RJ, Cloud G, Gruber W, Storch GA, Demmler GJ, et al. (1996) Ganciclovir treatment of symptomatic congenital cytomegalovirus infection results of a phase II study. National Institute of Allergy and Infectious Diseases Collaborative Antiviral Study Group. J Infect Dis 175:1080-1086.

18. Zhong XY, Ma TY (1993) Aclinical study of cytomegalovirus infections during prograte. J Tongji Med Univ 13: 60-64. 